\title{
O lugar do trágico no espetáculo Mount Olympus, de Jan Fabre
}

The place of the tragic in the spectacle Mount Olympus, by Jan Fabre

\section{Lisandro Bellotto Marta Isaacsson}

Lisandro Bellotto Ator, diretor, doutor pelo Programa de Pós-Graduação em Artes Cênicas da Universidade Federal do Rio Grande do Sul (PPGAC/UFRGS)

Marta Isaacsson Professora doutora do Programa de Pós-Graduação em Artes Cênicas da Universidade Federal do Rio Grande do Sul e do Departamento de Arte

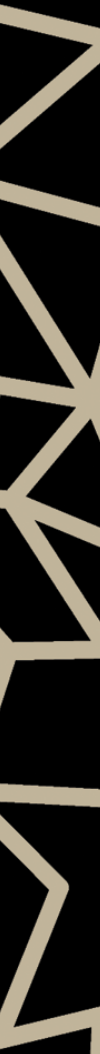

Dramática (UFRGS/DAD)

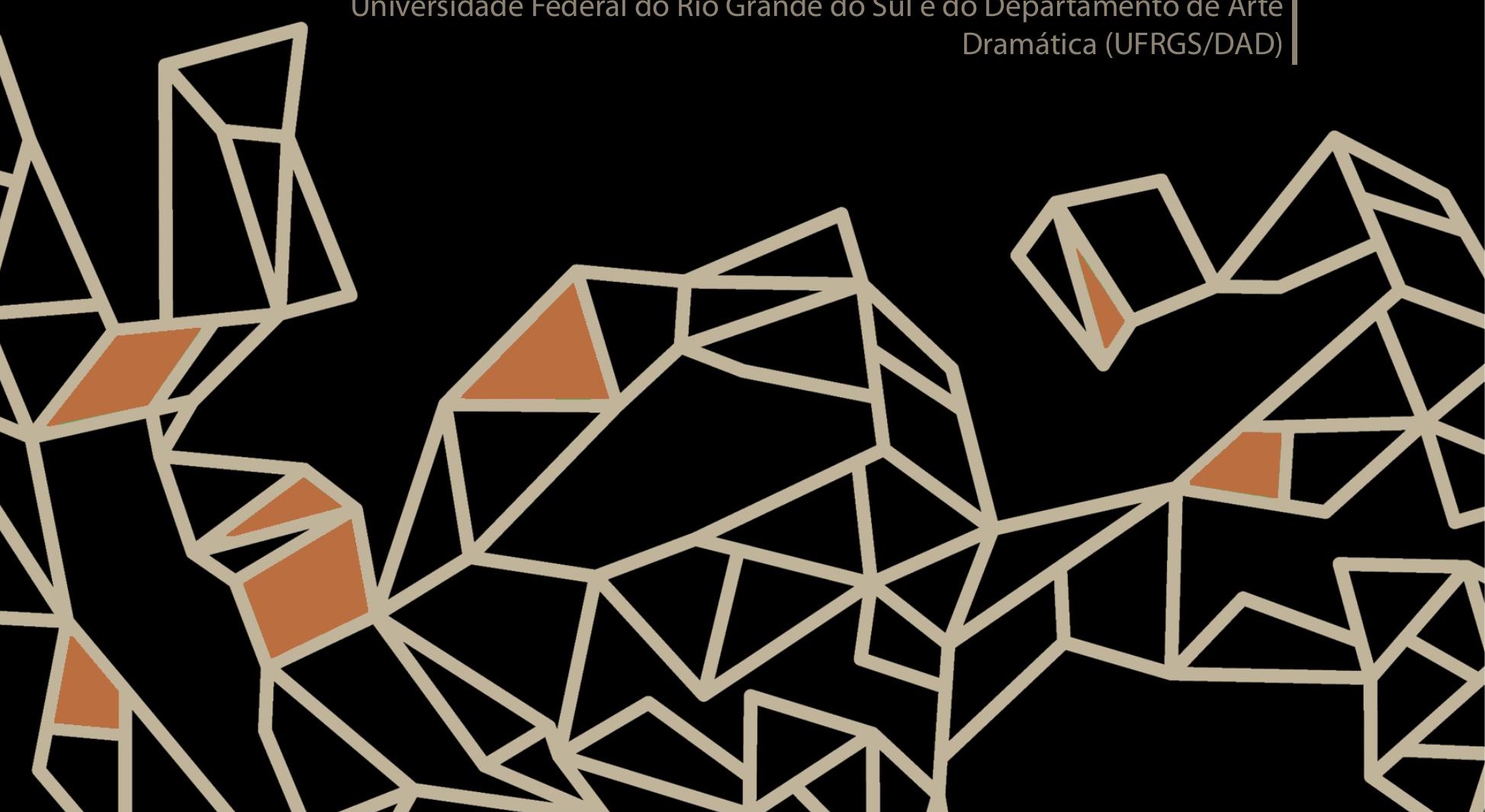




\section{Resumo}

No centro da reflexão encontra-se o espetáculo Mount Olympus, do renomado criador belga Jan Fabre, obra fundada nas paixões e tramas presentes na dramaturgia clássica grega. A dimensão do trágico torna-se, então, o foco de interesse da análise dessa monumental criação que atualiza, com suas 24 horas de duração, tanto o contexto das longas jornadas dos festivais dionisíacos, quanto a potência catártica do teatro grego por meio da empatia despertada pelo desgaste dos corpos dos performers. A reflexão recorre ao pensamento do filósofo Friedrich Nietzsche e às ideias teatrais de Antonin Artaud para colocar em evidência a importância do coro e a exploração da dilatação do tempo na composição do trágico. Palavras-chave: Mount Olympus, Jan Fabre, Trágico, Cena contemporânea.

\section{Abstract}

At the center of the reflection is the Mount Olympus spectacle of the famous Belgian creator Jan Fabre, a work founded on the passions and plots present in classical Greek dramaturgy. The dimension of the tragedy then becomes the focus of interest in the analysis of this monumental creation which updates, with its 24-hour duration, both the context of the long days of the Dionysian festivals and the cathartic power of the Greek theater through the empathy aroused by the weary bodies of the performers. The reflection rests on the thoughts of the philosopher Friedrich Nietzsche and the theatrical ideas of Antonin Artaud to highlight the importance of the choir and the exploration of the expansion of time in the composition of the tragic.

Keywords: Mount Olympus, Jan Fabre, Tragic, Contemporary scene.

A natureza efêmera das artes da cena compromete a sua preservação. Por isso mesmo, torna seu espectador uma testemunha. São nas lembranças imagéticas e afetivas, nas tensões e deslocamentos perceptivos impressos no corpo, memória do participante anônimo, o espectador, que a criação cênica se prolonga no tempo. Imbuídos do papel de testemunha e diante de obra de envergadura excepcional em múltiplos aspectos, escolhe-se aqui partilhar os rastros em nossa memória deixados pelo espetáculo Mount Olympus, para glória e culto da tragédia, do belga Jan Fabre, buscando colocar em evidência o lugar do trágico nessa obra construída a partir de grandes clássicos do teatro grego. 
A potência de seus espetáculos, compostos na interface da beleza visual e da violência, fez de Jan Fabre um dos grandes nomes da cena contemporânea. Em paralelo a uma significativa produção no campo específico das artes visuais, Fabre traz em seu currículo espetáculos marcantes da história recente das artes cênicas, como C'est $d u$ théâtre comme c'était à espérer et à prévoir (1982) e Le Pouvoir des folies théâtrales (1984). A motivação para assistir a Mount Olympus havia sido despertada muito antes da estreia do espetáculo, em 2013, em conversa ocorrida por ocasião do Simpósio da Sociedade Bertold Brecht realizado em Porto Alegre'. Absolutamente lisonjeado, o crítico teatral Hans-Thies Lehmann nos confidenciava o convite do artista flamengo para participar da equipe responsável pela dramaturgia de sua próxima criação entorno de tragédias gregas. A leitura do célebre estudo Teatro pós-dramático (1999), de Lehmann, permite facilmente compreender a afinidade entre crítico e artista, motivadora da parceria. As criações de Fabre integram o corpus de análise por meio do qual o pesquisador fundamenta sua argumentação em favor do surgimento, desde os anos de 1970, de uma cena teatral organizada sob princípios operatórios distintos do modelo dramático. Lehman encontra nos espetáculos de Fabre referências do que define como signos pós-dramáticos, como o jogo proposital entre realidade e ficção (LEHMANN, 1999, p. 168); as fronteiras fluídas que aproximam o teatro da arte performática (Ibid., p. 223); o recurso à repetição, que funciona como elemento de perturbação e agressividade (Ibid., p. 309); as características de uma estética da duração, tendo a dilatação temporal como traço dominante (Ibid., p. 306), onde o comportamento físico e psicológico do performer é testado em cena (lbid., p. 308), entre outros.

O sol ainda brilhava sobre o Canal de l'Ourcq de Paris naquele 15 de setembro de 2017, quando o espaço cênico do Grande Halle de la Villette abria suas portas para acolher o público de Mount Olympus. A corrida frenética dos espectadores em busca dos melhores lugares comprometia o reconhecimento da infraestrutura de apoio cuidadosamente prevista para atender às necessidades do público no curso das 24 horas contínuas de espetáculo.

1 No mês de maio de 2013, a International Brecht Society promoveu, em colaboração com o Programa de Pós-Graduação em Artes Ciências da Universidade Federal do Rio Grande do Sul (PPGAC/UFRGS), o 14 Simpósio sob o título "O espectador criativo: colisão e diálogo". 
Os espaços de restauração tradicionais do La Villette ganhavam reforço com a instalação de food trucks disponíveis para refeições, cafeteria de serviço contínuo, espaços com camas para descanso, grandes almofadões e espreguiçadeiras espalhados pelos corredores e cabine de massagens, tudo disponível para o conforto dos espectadores, além de uma complexa estrutura de backstage para atender a demanda de produção dos performers e do palco durante a apresentação.

Carregando biscoitos, água, almofadas e agasalhos, os espectadores entram preparados para uma longa jornada teatral. A duração prolongada da experiência teatral não constitui o único fator que remete ao tempo dos festivais dionisíacos de Epidauro. Heróis das tragédias de Ésquilo, Sófocles e Eurípides alimentam a dramaturgia organizada por Miet Martens, a partir de textos de Jan Fabre, Jeroen Olyslaegers, e apoio de Hans-Thies Lehmann, Luk Van den Dries e Freddy Decreus. Falado em quatro línguas e reunindo 22 performers; quatro gerações de artistas parceiros de antigas criações de Fabre. O espetáculo, composto por 14 capítulos e três pausas consagradas aos sonhos (temps de rêves), que conformam um total de 120 cenas, resgata elementos de obras trágicas da Grécia Antiga, e estabelece uma cartografia das pulsões e desejos proibidos do homem.

Grande parte das cenas está estruturada como tarefas ou ciclos de atividades prolongadas e repetitivas (procedimento chave na poética do encenador). Os performers correm no mesmo lugar enquanto enunciam palavras gritadas; realizam mais de 300 piruetas em trajetória circular; pulam corda até a fadiga; se debatem no chão durante 30 minutos; caminham contraindo todos os músculos do corpo até fazê-los vibrar; se deslocam com boca e olhos vendados, dificultando a visibilidade e respiração. Estas são algumas das atividades que se sucedem no decorrer de um dia inteiro. Tarefas que poderiam constituir um treinamento militar ou do atleta, se alternam com a apresentação de heróis clássicos da mitologia grega. Se evidencia a cada atividade o drama do corpo que provoca uma intensidade física e resiste a ela.

A duração estendida do espetáculo autoriza o público francês a transgredir suas normas estritas de convivência no espaço teatral. Algumas horas após o início do espetáculo, os espectadores não se inibem em entrar e sair, 
sussurrar, comer, beber e dormir na plateia. Ninguém reclama, afinal é tempo de desmedida. A liberdade de movimentos do espectador se instaura e faz ecoar o clima das plateias do tempo das grandes dionisíacas.

\section{O êxtase dionisíaco do coro na origem da tragédia}

Fabre traz à cena grande número de importantes personagens de peças teatrais gregas, Etéocles, Hécuba, Ulisses, Édipo, Creonte, Jocasta, Penteu, Fedra, Hipólito, Alceste, Hércules, Clitemnestra, Agamêmnon, Ifigênia, Cassandra, Electra, Orestes, Medeia, Jasão, Antígona, Crisipo, Ajax, Dario e Filoctetes. Não há, no entanto, nenhum compromisso de fidelidade com a dramaturgia de referência. Heróis e tramas se articulam com vista a condensar a intensidade de desejos e impulsos mitológicos em imagens cênicas caracterizadas, simultaneamente, por beleza e brutalidade.

Nenhum desses famosos personagens do teatro antigo detém, porém, o protagonismo do espetáculo, então deslocado para o coro e cujas intervenções dançadas se faz no curso de toda a criação. São os performers componentes do coro que, sob suas vestes, carregam o símbolo material da tragédia, as vísceras cruas de animais. São as pulsões de seus corpos, em longas cenas de êxtase físico, que fazem expirar o sangue entranhado nas vísceras, tingindo o branco de suas vestes e contaminando o palco. Entres convulsões e prazeres desmedidos, o movimento dos corpos do coro desnuda o fardo da tragédia. Mas a tragédia profunda e entranhada nos corpos não impede o homem de fazer festa e é a uma dança festiva que os performers se entregam no início e final do espetáculo. A danse rituelle extatique (dança ritual estática), que acompanha o prólogo, remete à carnavalização e à celebração da vida, da carne e suas pulsões de morte e vitalidade. Ao som da twerk dance os movimentos são vigorosos e agressivamente sensuais. Onze performers realizam gestos provocantes, circulares e repetitivos, para frente e para trás, com o quadril e tronco, e deslizam até o chão. Movimentos eróticos que remetem aos sentidos de prazer: luxúria, libertinagem, volúpia, lascívia, e todo leque de manifestações de conotações sexuais (coxas, torso e órgãos sexuais ficam visíveis quando se movimentam). Uma atmosfera de permissividade se estabelece 
e se adensa quando os performers simulam o ato sexual - afinal, no plano narrativo se está no reino dionisíaco.

Em meio ao coro composto por performers uniformemente vestidos de branco, no curso da dança vibrante de seus corpos esculturais, surge uma figura grotesca, robusta, com grande ventre a mostra, cachos de uvas plásticos. Trata-se da figura fantástica e repugnante do sátiro que segundo Nietzsche, personifica a "imagem primitiva do homem, a expressão de seus maiores e mais fortes impulsos" (NIETZSCHE, 1948, p. 80). Ele dança, realiza gestos obscenos, comanda os movimentos do coro, por vezes toca instrumento de percussão para ressaltar o tempo ritmo da música e da dança, acaricia e beija os performers. A coreografia se desenvolve entre inúmeros pedaços de carne crua que se desprendem do corpo dos performers, enquanto a figura de Dionísio passeia entre o coro dançante e os corpos mortos e fragmentados das carnes que começam a tomar conta do palco.

O protagonismo adquirido pelo coro em Mount Olympus reverbera o pensamento de Nietzsche sobre as origens da tragédia antiga, para quem "o coro satírico, nascido do cortejo de servos de Dionísio, constitui a grande matriz do universo trágico" (NIETZSCHE, 1948, p. 76). O coro não só esconde nas suas entranhas o germe da tragédia, materializada pelas vísceras, mas é dele que surgem os heróis com suas paixões e desejos proibidos. Assim, sobre a cena de Fabre, o aparecimento dos personagens mitológicos é sempre precedido por uma longa cena do coro, construída sobre o princípio da exploração dos limites e do arrebatamento físico dos corpos. A tragédia é sempre precedida pela orgia. Os heróis se personificam, então, como visão, como projeção da pulsão do grupo de sátiros. Dionísio deixa de se expressar como força para se fazer presente como herói épico, tal qual imaginado por Nietzsche (1948, p. 89). Em seu entusiasmo dionisíaco, o coro projeta "uma visão para fora de si, como complemento apolíneo de seu estado" (NIETZSCHE, 1948, p. 85). Enquanto projeções da multidão dionisíaca, as personagens de Fabre são destituídas de realidade, como imagina o filósofo alemão. O caráter não realista da representação das personagens vem impresso no tratamento visual dos corpos pintados de branco e vermelho, descarnados de vida e que vagam pelo palco, como o fantasma de Dario. Ou 
figuras que golpeiam o espaço vazio, presos numa batalha sem fim, como 0 guerreiro Ulisses.
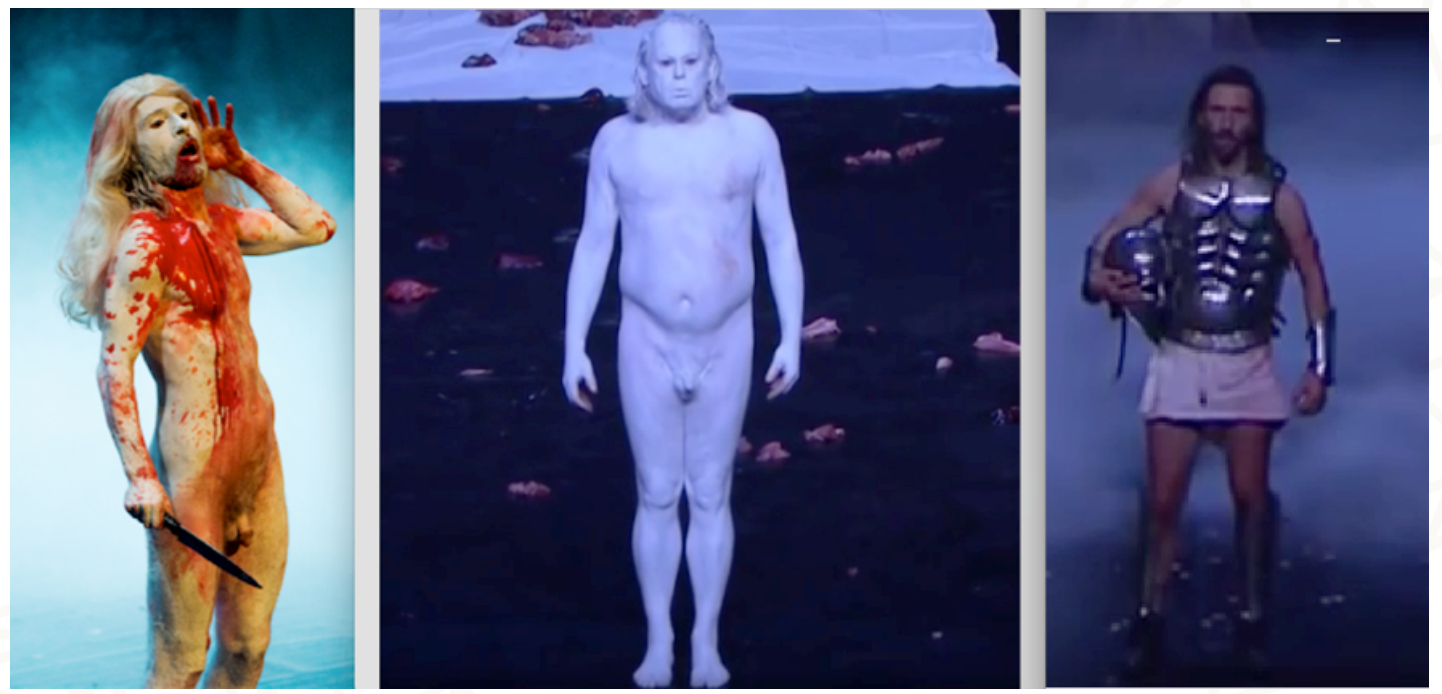

Figura 1 - Imagem de sonho, fantasma de Dario e guerreiro Ulisses Frames: Registro videográfico do espetáculo, 2017

Ou ainda, enunciando longos monólogos aos gritos e em alta voltagem física, após sessão intensa de exercícios desgastantes, como o personagem Etéocles.

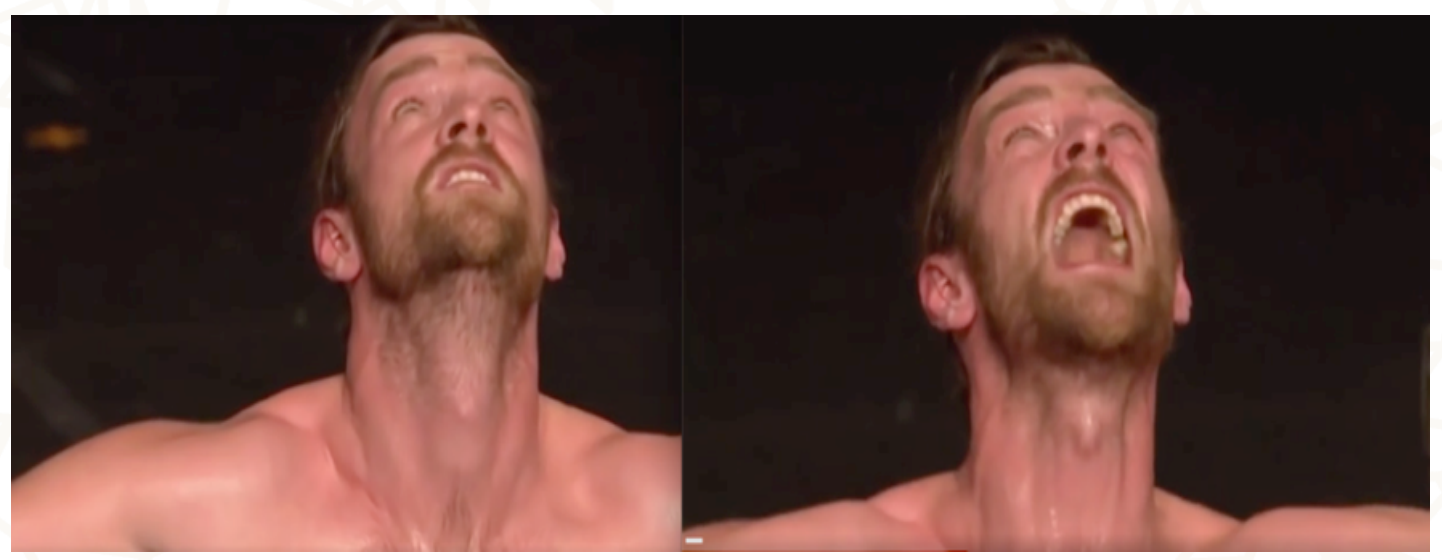

Figura 2 - Guerreiro Etéocles

Frames: Registro videográfico do espetáculo, 2017

São os impulsos dos corpos, a fisiologia do homem, que dá origem à tragédia. "O mundo do palco, o dos personagens e da trama, constitui então um mundo apolíneo de espectros do coro satírico" (NIETZCHE, 1948, p. 83, grifo do autor). Graças à duração estendida e à exigência de alto desgaste físico dos performers, as cenas do coro de Fabre cumprem exatamente a função do coro ditirâmbico que, segundo Nietzsche, era de 
excitar o ânimo dos ouvintes dionisiacamente até um certo grau, a fim de que estes, ao aparecer o herói no palco, não vejam o homem disformemente fantasiado e mascarado, mas sim uma figura de visão, nascida de seu próprio êxtase. (NIETZSCHE, 1948, p. 88)

Ao frénésie das cenas do coro se contrapõem imagens fixas projetadas sobre a rotunda. Elas avançam figuras mitológicas que se farão presentes, ou lembram aquelas que já passaram pelo palco. A antecipação e o resgate da imagem revelam o tempo como um fenômeno cíclico e de repetição. Diferentes, no entanto, são as perspectivas sob as quais as figuras aparecem: ora virtuais e atomizadas, ora reais e pulsantes. Como a eternidade divina é atemporal, os mitos que controlavam o sistema moral da Grécia Antiga retornam no palco da sociedade cristã. A contenção dos impulsos vem impressa na figura que remete a Cristo e que aparece múltiplas vezes sobre diferentes ângulos, recordando a pressão judaico-cristã que torna trágica a nossa própria existência.
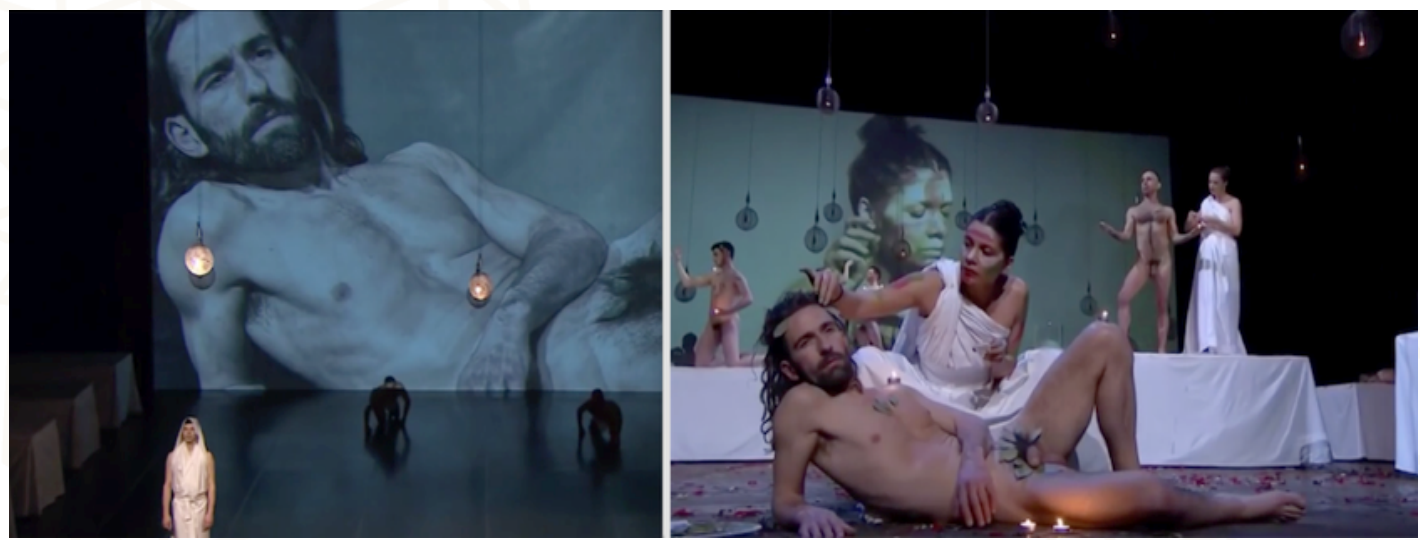

Figura 3 - O Cristo nu

Frames: Registro videográfico do espetáculo, 2017

O uso da fotografia demonstra a opção por imagens congeladas que acumulam o tempo, em vez da variedade que o mata (LEHMANN, 1999). Elas somam, repetem e prolongam o tempo. Em outro momento, enquanto uma figura de sonhos aparece ao fundo do palco (corpo pintado de branco com o peito rasgado por corte), por sobreposição, uma foto em negativo é projetada. A imagem manipulada transforma a figura em espectro, o duplo explorado na foto pelo seu inverso. As figuras desencarnadas em imagens virtuais também apresentam os indivíduos que se destacam da coletividade do coro: a relação fotográfica do teatro com o culto dos mortos. 


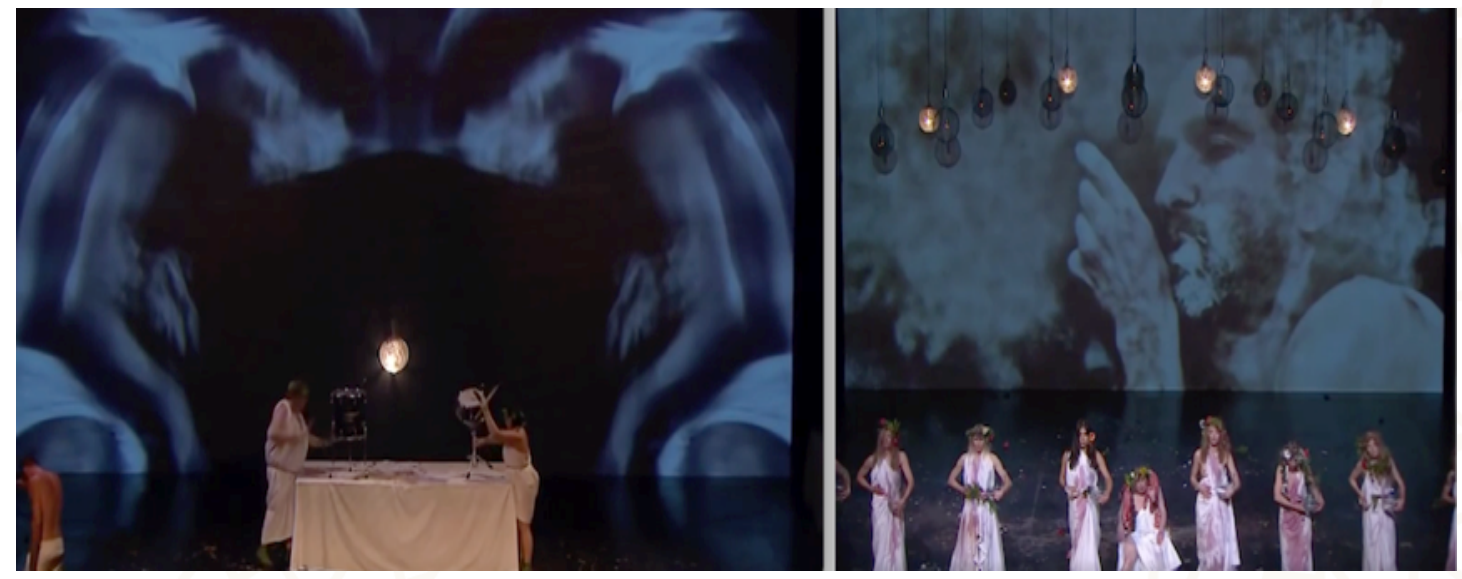

Figura 4 - Projeções em Mount Olympus

Frames: Registro videográfico do espetáculo, 2017

\section{A peste imposta pelo tempo}

O caráter excepcional do espetáculo se afirma para além da duração estendida. Subir ao monte Olimpo é suportar o ar rarefeito. A cena de Fabre se constrói pela submissão dos corpos a ritos físicos extenuantes e onde toda forma de pudor está banida. Enquanto Fabre encontra-se na cabine de controle de luz e som, Artaud está certamente nas coxias. Embora respeite a quarta parede e não faça uso do espaço circular artaudiano, Mount Olympus traz ao palco o corpo acometido pela peste, submetido a um mal superior, tão desejado por Artaud. Na cena de Fabre, a destruição é engendrada pelo tempo. O mal superior é o tempo. Sob a ação do tempo, o corpo se desgasta e termina por se desfazer. É contra o tempo que os guerreiros da beleza ${ }^{2}$ lutam, procurando vencer o cansaço, a dor, manter o fôlego e a energia. A luta de caráter eminentemente físico do sujeito com ele mesmo faz emergir seus líquidos - suor, lágrimas, sangue, urina e saliva - e desnudar a verdade fisiológica da existência e as pulsões do animal-homem.

O desgaste dos corpos aciona energia extra, que se traduz em presenças marcantes em cena. Nesse processo, as transformações físicas

2 Expressão utilizada pelo encenador para denominar seu grupo de performers que resiste às pressões física e mental exigidas pelas cenas e, assim, resiste ao inevitável desaparecimento da vida. 
se tornam visíveis no palco, através da acentuação da realidade biológica do corpo: sistema circulatório, digestório, excretor, respiratório, sanguíneo, nervoso e tegumentar. Todo o aparato sensório-físico do performer é acionado, fazendo com que a organicidade desse corpo seja colocada em evidência na encenação. Estados físicos diversos, a expulsão de fluidos, aumento dos processos respiratórios, emoções que afloram como consequência do esforço praticado e o uso do grito, são alguns dos elementos que contribuem para a visibilidade da matéria orgânica friccionada no palco. Em uma das cenas iniciais, denominada de "Chien de rue et vautour sur le champ de bataille abandonné" (Cachorro de rua e abutre sobre o campo de batalha abandonado), a atriz mais antiga do grupo, Els Deceukelier, percorre o palco caminhando de quatro. Ela representa um cachorro faminto, recolhe as inúmeras poças de carne espalhadas, esfrega no corpo, coloca na boca, mastiga e regurgita a matéria esfacelada. Enquanto seu corpo se tinge de vermelho do sangue, ela empenha força e velocidade para se movimentar de forma ágil. Completamente hipnotizada ela se comprime, tem espasmos, seu corpo se crispa, ela rola no chão de maneira furiosa. Como se estivesse numa espécie de transe, durante 15 minutos a mulher-animal revela algo de assassino. Ela grita, chora e agoniza até sua lenta morte ao final da cena, em que se percebe a atriz banhada em suor, completamente exaurida pelo esforço intenso. Já no capítulo quatro, a cena denominada "La danse extatique des Ménades" (A dança estática das Ménades), as atrizes, em posição fixa, giram em volta de si pedaços de carne crua. A cena inicia de forma lenta, com movimentos circulares na lateral do corpo e em cima da cabeça. Com o passar do tempo, a intensidade aumenta, e a fadiga muscular vem acompanhado de gritos e gemidos. Elas esfregam a carne nos órgãos genitais, hipnotizadas pela repetição frenética. Giram as vísceras como se fosse um relógio em velocidade fabrineana, como o tempo da própria maldição trágica, que passa de uma geração à outra. A peste toma conta do palco. A cada nova cena em que o tempo e o movimento circular agem sobre o corpo, uma nova dimensão nasce: o portal para a condução da peste. O motor gerador de tais qualidades físicas, que acionam os órgãos internos, é mostrado em cena. Uma energia que é produzida e desgastada no tempo longo do seu fazer. 


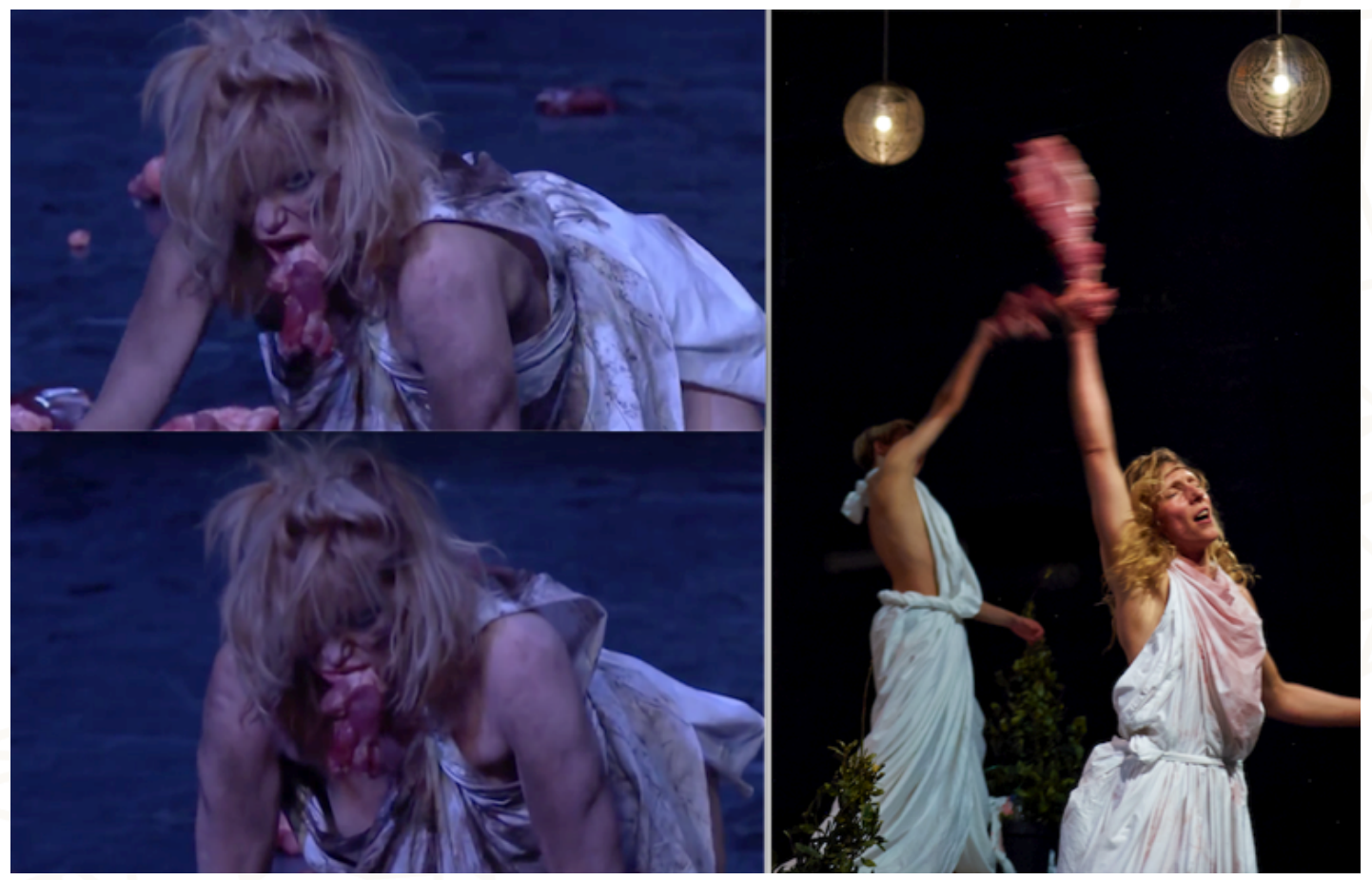

Figura 5 - Cachorro de rua e Dança das Ménades

Frames: Registro videográfico do espetáculo, 2017

Se observa que a vida biológica em pleno movimento e desgaste reforça a presença vital do performer, que se encontra dentro de uma cena transformada em dispositivo atlético. O espaço do palco preenchido pela materialidade orgânica em combustão. Com o passar do tempo, as trocas físicas do corpo com o ambiente se multiplicam; o suor que escorre encharca o palco, banha os corpos, ouve-se o ritmo frenético do coração pela respiração acelerada, as palavras gritadas se materializam como pedradas dirigidas à plateia, sente-se o calor que emana desses corpos por empatia. O performer dança, geme, grita, corre, pula, hiperventila, se desgasta, se debate, valendo-se da violência, sensualidade, deformação e resistência, para em seguida, apresentar figuras emblemáticas da antiguidade grega em seu estado arquetípico. O palco fisicalizado assim se aproxima do espaço que propunha o autor do teatro da crueldade: um lugar a ser preenchido de forma visceral pela materialidade de corpos e vozes:

Sacudindo a inércia asfixiante da matéria que atinge até os dados mais claros dos sentidos e, revelando para a coletividade o poder obscuro delas, sua força oculta, convida-as a assumir diante do destino uma atitude heroica e superior que, sem isso, nunca assumiriam. (ARTAUD, 2006, p. 29) 
Artaud insistiu em aliciar arte e vida. Fabre, ao colocar o performer em situações extremas, frente à realidade de um esforço que necessita resistência e resiliência, empurra este para além da situação teatral fictícia. A camada ficcional se faz presente juntamente com situações físicas reais. Ações que colocam o corpo em teste, que o obrigam a ultrapassar suas capacidades aparentes, investindo na dimensão real da tragédia. O Troubleyn, como uma equipe de atletas, tem os sentidos experimentados e aguçados em treinamento. Esse estado sensorial e motor trabalhado é acionado em cena, amplificando sua presença, porque o coloca no presente absoluto, já que lida com o risco, com o aqui-agora da representação.

Nessa tragédia, o conflito intersubjetivo tradicional do drama cede lugar ao embate entre o homem e o tempo; ele se traduz na busca obstinada por vencer os limites do corpo diante da passagem do tempo. A grande provação do homem é imposta pelo tempo e a experiência da peste se faz na repetição exaustiva dos movimentos. Na cena "Apprivoisement du serpent par Ulysse" (Domesticação da serpente por Ulisses.), quando as pernas e braços já não suportam mais, a grossa corrente cai das mãos do performer ressoando no chão e anunciando a derrota. Mas o guerreiro da beleza não pode esmorecer. O performer retoma a corrente, ele a ergue e com ela dá seguimento ao jogo infantil de pular corda. É preciso saltar sobre a corrente, é preciso transgredir os limites do corpo, vencer o cansaço imposto pelo tempo ou, pelo menos, tentar.

A repetição incessante do movimento agencia o conflito e materializa a tirania do tempo sobre o homem. Por essa razão, os espectadores não conseguem se manter impassíveis diante da luta de duas bailarinas na cena "Manège de Clytmnestre e Iphigénie autor d'Agamemnon" (Passeio de Clitemnestra e Ifigênia em volta de Agamemnon). Ao presenciar o cambalear, a parada, a queda das bailarinas no exercício interminável de giros sobre si mesmas e entorno da figura de Agamenon, o público se comove. Identificado com a exaustão, com a dor muscular, com o fôlego ofegante das bailarinas, ele as incentiva por meio de palmas ritmadas, como se pudesse nutrir seus corpos de energia. A impotência em vencer o tempo se revela então a miséria de toda humanidade. Esse é o lugar do trágico de todos nós. 
A perseverança na tarefa física faz lembrar princípios da prática teatral de Grotowski. Entretanto, em Fabre, a persistência na execução do exercício não é um meio, não se faz em prol do acesso a um estado excepcional no qual se fará a manifestação de signos orgânicos, como preconizava Grotowski (1933-1999). A resiliência dos guerreiros da beleza é por si mesma signo, expressão da luta contra a destruição dos corpos pelo tempo. Uma luta que é de todos nós e por isso os aplausos energizantes do público. Enquanto o conflito humano entre máscara social e impulsos interiores constituía, na concepção de Grotowski (1987), o solo comum de verdade capaz de promover a comunhão ator-espectador, tão necessária ao teatro, em Fabre o encontro sagrado se estabelece na dor coletiva do limite dos corpos. A tragédia dos limites dos corpos é o solo de nossa comunhão.

\section{Referências bibliográficas}

ARTAUD, A. 0 teatro e seu duplo. São Paulo: Martins Fontes, 2006.

GROTOWSKI, J. Em busca de um teatro pobre. Rio de Janeiro: Civilização Brasileira, 1987.

LEHMANN, H-T. Teatro pós-dramático. São Paulo: Cosac Naify, 1999.

NIETZSCHE, F. A origem da tragédia, proveniente do espírito da música. São

Paulo: Cupolo, 1948.

Recebido em 21/02/2019

Aprovado em 12/06/2019

Publicado em 30/08/2019 